\title{
TOWARDS AN UNDERSTANDING OF UNIVERSITY STUDENTS' RESPONSE IN TIMES OF PANDEMIC CRISIS (COVID-19)
}

\author{
Ioannis Kamarianos ${ }^{i}$, \\ Anthi Adamopoulou, \\ Haris Lambropoulos, \\ Georgios Stamelos \\ Department of Education \\ and Social Work, \\ University of Patras, \\ Greece
}

\begin{abstract}
:
In response to the need for more research evidence, as an empirical base for discussion on the experiences of young people, the current study aims to contribute to the discussion on their attitudes and behaviors in times of pandemic crisis. It is of great importance, that under the pressure of social limits on social distancing for the novel Coronavirus (COVID-19), young students have to adapt more efficiently with new technologies both every day and for educational practices, where their experiences involve multiple, complex and overlapping social and digital universes. According to the findings of this study, it is clear that as long as universities were closed, most of the/our young students did not have any difficulty in switching to online teaching. In addition, the participants' responses show that as Gen Z's, they want to have the ability to learn new skills and make new experiences.
\end{abstract}

Keywords: pandemic crisis, COVID-19, digital natives, Generation Z

\section{Introduction: Connecting in Times of pandemic crisis}

It is well known among researchers that technology can facilitate our everyday lives, especially under the pressure of pandemic crisis' demands for social distancing experienced worldwide.

More specifically, these demands within the academy convey a sense of urgency that pressures students to keep up with changes and raises concerns that some students may be being left behind.

\footnotetext{
i Correspondence: email kamarian@upatras.gr
} 
In the past, the debates about the exposure of 'new students' to educational (Maton 2004) or technological (Hickox \& Moore, 1995) change were common.

Generations of students have been portrayed as baby boomers, generation $X$, Generation Y digital natives (Prensky, 2001), or Net Generation (Tapscott, 1998). Some of the main questions emerging from these conceptions refers to the degree of technological readiness of young people, their digital skills level and whether and how they are used in the educational process.

The common characteristic of young Greek students entering university nowadays is that they widely use technological media and can reach the kind of natural fluency that comes along with having grown up with new digital technologies. The phenomenon is not new. It has been portrayed in other Higher Educational Areas as well. For instance: the Vice Chancellor of the Open University (UK) had this to say to the University Council:

"Most of our students, moreover, are part of what we now describe as the Net Generation. This is a generation who think IM, text and Google are verbs not applications! They expect to be engaged by their environment, with participatory, sensory-rich, experiential activities (either physical or virtual) and opportunities for input. They are more oriented to visual media than previous generations - and prefer to learn by doing rather than by telling or reading. They explicitly prefer to discover rather than be told." (Jones et al., pp. 723.)

Furthermore, empirical work that examines the profile of young university students finds that the generation currently entering university is more complex than the literature would lead an observer to expect. In their research concerning the use of technologies, Kennedy et al. (2008) found that amongst first-year Australian students there was significant diversity when looking beyond the basic and entrenched technologies.

They found that the patterns of access to, use of, and preference for a range of other technologies varied considerably. They argued that their findings ran counter to many of the assumptions that underpin both the idea of the Digital Native found in Prensky (2001a) and the similar set of ideas advanced by Tapscott using the term Net generation (Tapscott, 1998; 2008). They went on to suggest, that the fundamental changes that have been proposed to accommodate the claims made about the characteristics of this new generation of learners didn't seem to be warranted by the evidence they had gathered (Jones et al., 2010).

They also note that this poses a certain difficulty because the generational grouping showed a high degree of technological diversity.

In response to the need for more research evidence, as an empirical base for discussion, the current study aims to contribute to the discussion on the experiences of young people (university students) and especially on their attitudes and behaviors in irregular times like the pandemic crisis. 
It is of great importance, that under the pressure of social limits on social distancing for the novel Coronavirus (COVID-19), young (university) students have to cope more efficiently with new technologies on a daily basis and particularly for educational practices involving multiple, complex and overlapping social and digital variety of abilities.

\section{Research question}

In an attempt to better understand and conceive the core characteristics of the young population as a distinctive generation, the current study aims to approach and examine the reaction of the students - and to a certain degree their capability to respond to the emerging demands of rapidly changing attitudes and behaviors in a digital framework, as a result of the pandemic crisis.

The central research question of the study focuses on whether Greek (university) students showed different attitudinal and behavioral responses towards the use of ICTs in the abrupt times of the pandemic as compared to their previous routine. In addition, the current study also explores whether students, as digital natives, cope more efficiently with the current social consequences of the Coronavirus pandemic crisis.

The underlying assumption is that according to their generational characteristics Greek (university) students respond adequately to the demands emerging from the unprecedented restrictions imposed on social interaction, because of the pandemic.

\section{Conceptualizing the issues}

According to the poll conducted by the Associated Press-NORC Center for Public Affairs Research, it is the younger people (ages 18-29) who are the most concerned about someone becoming infected in their home (see Table 1). The poll also showed that millennials are not taking the situation as seriously as generation $\mathrm{Z}$ does (AP \& NORC 2020).

The terms 'Millennials' (Oblinger and Oblinger, 2005), 'Next generation' or 'generation Z' (Tapscott, 1998, Tapscott, 2008) and 'Digital natives' (Prensky, 2001a; Prensky 2009; Jones et al, 2010) are the most recent and commonly used to describe the generation of young people, who are currently attending university worldwide. In saying so, these terms are used in order to identify a generation of young people who are now studying at the universities based on their skills and abilities.

But if the youngest millennials are now twenty-four and the oldest of the $\mathrm{Z}$ generation are only twenty-three, how can we support a dived? The criteria used to define these terms are mainly chronological. Scholars such as Tapscott (1998), Oblinger \& Oblinger (2005), or Palfrey \& Gasser (2008) draw the importance of a precise date over some generational characteristics. For example, according to Oblinger and Oblinger (2005) Millenials were born in 1982 and after. Jones, Ramanau, Cross and Healing (2010), in order to define the generation of digital natives, adapt the almost universal claim that 
"this Net generation of Digital Natives is marked out by clear boundaries in terms of their attitudes" (Jones et al. 2010, p.2). Corey Seemiller and Meghan Grace (2019) in their study, Generation Z: A Century in the Making, which aims to prepare college administrators and educators for a new generation of college students, defined as generation $\mathrm{Z}$.

Table 1: How worried are you that you or someone

in your family will get infected with coronavirus?

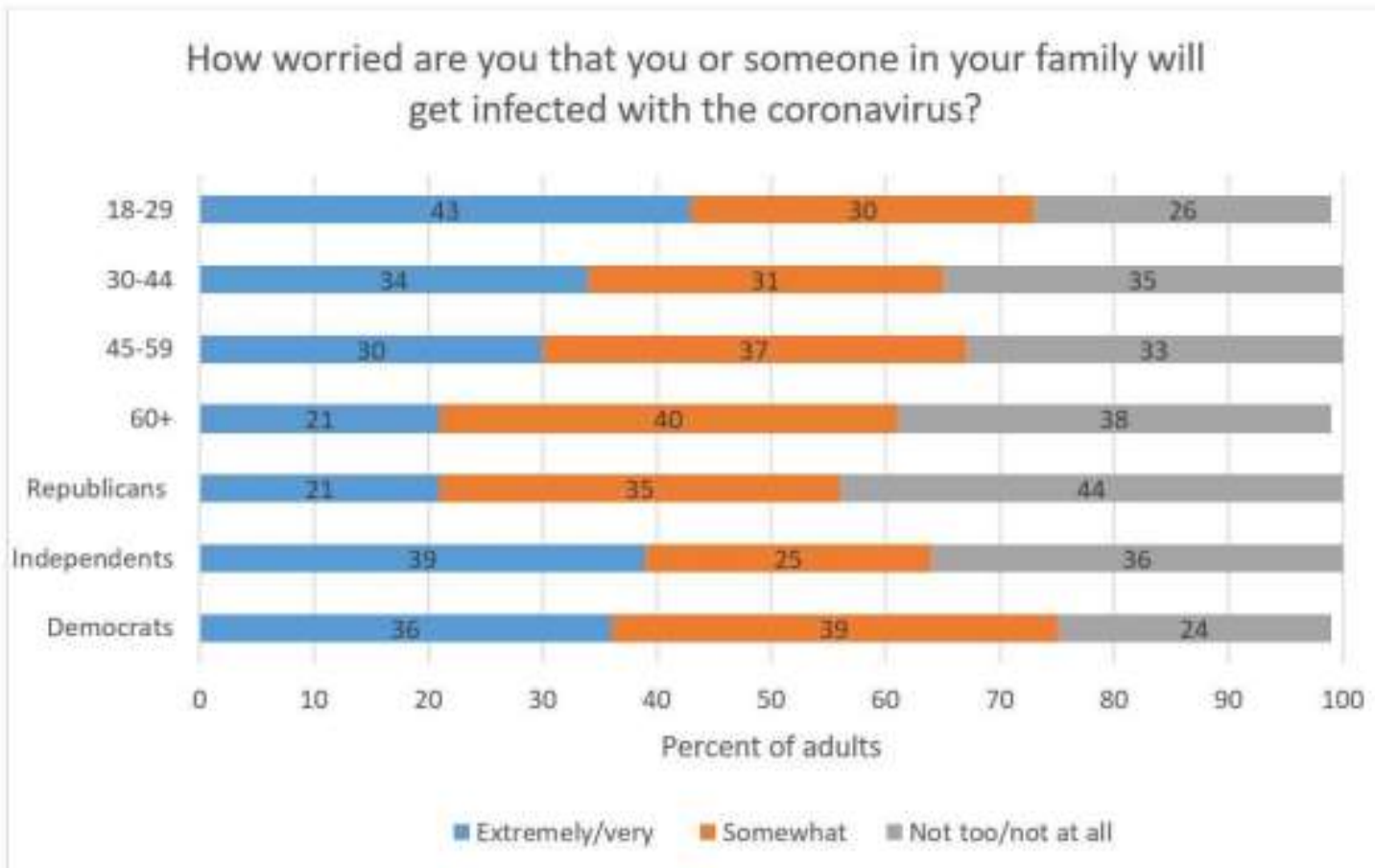

Question: How worried ore you about you or someone in your fomily being infected with the coronavirus? Source: AP-NORC Poll conducted March 12-16, 2020, with 1,003 adults.

Marcie Merriman, in the Ernst \& Young's study: What if the next big disruptor isn't a what but a who? Gen $Z$ is connected, informed, and ready for business (2015) adopts the chronological definition. According to her study Generation Z was born in 1997 (p.3). In the meantime, firms like Amazon and eBay were created (in 1995) as the Internet was commercialized and Microsoft released Windows 95. Merriman focuses on the political, economic, social, and technological changes that form the core characteristics of Generation Z. More specifically, for those born after 1997 four essential topics form a common set of behaviors, attitudes, expectations, and ambitions. The key factors that differentiate Generation $Z$ are self-awareness, persistency, realism, innovation, and selfreliance (Marriman, 2015, p.3). More concretely, Gen Z has grown up into a world where the attaining of gender and racial equality has been important, especially in schools. But, unlike millennials where gender was a stable identity, Gen Z was born in times of gender diversity and liquidity, "gender is increasingly more fluid and nondescript" (Marimman, 2015 p. 4).

Liquidity and dynamic change have increased because of modern technology. Generation Z was the first generation which unlike Millennials, indorsed the introduction 
and rise of social media. Gen $\mathrm{Z}$ wants to work with cutting-edge technology and is eager to share its knowledge (Dimensional Research, 2018). According to Marriman (2015), the current generation consists of true digital natives. For them, this is a technological world (Mack \& Palley, 2012). Gen Zs grow up online, socially connected to friends. They are constantly connected to their social networks - both real and digital. As digital natives, they exhibit different preferences and communicative attitudes and behaviors to older people. For instance, they are described as constantly connected with plenty of friends on social networking sites. Socializing digitally is more convenient. They were born in a world where they can connect instantly and look up the answer to any question or friend that crosses their mind (Jones et al., 2010, p. 727). There is no need for human interaction to answer their questions. As a hyper-connected generation, they participate in real and digital networks in traditional but also with innovative ways. One of the most important effects of this process of connectedness is generation $Z^{\prime}$ 's multicultural and global conception of everyday life (Mack \& Palley, 2012).

Unlike Millennials' parents, Baby-boomers, who protected their children, awarded them prizes just for participation and acted as "helicopter parents," who hovered, guarded and were constantly involved, Gen Z's parents have moved towards preparing their boys and girls to cope with life's challenges anxieties and complications. Instead of being the "helicopter parents," they have become the "stealth fighters", monitoring, patiently explaining, reconceptualizing motives and redirecting actions if needed. Thus, Gen Zs emerged as more self-aware and self-reliant, since they were prepared by parental strategies for life complexities such as economic crises, school violence, unemployment and career difficulties (Merriman, 2015).

Because of this economic, social, and political environment, Gen Z endorses a pessimistic approach towards life perspectives. On a macro level, despite the parental support and guidance most of Gen Zs presume that everyday life is either staying the same or getting worse. We note that according to Mack \& Palley (2012) the main cause for these negative assumptions has been their concerns about the financial situation of their parents. More specifically, with the European economic-financial crisis comprising a considerable part of their life trajectories, Gen Zs are most likely to be anxious about their parents' financial situation. As a generation that has grown up in economic austerity (mainly in South Europe), Gen Z has inherited a set of economic, political, and social worries about their financial situation and they are already anxious about their future. Parental concerns cause their children anxiety. This anxiety drove generation $\mathrm{Z}$ to prepare themselves, by endorsing all the necessary attitudes and behaviors that are needed in order to enable them to achieve in the face of adversity. More concretely, the economic anxiety drives frugality (Mack \& Palley, 2012).

In conclusion, Gen Zs have always known turbulence and instability. They experienced the debt crisis, the biggest recession and worst employment rates since the 1930s, and now they experience a pandemic crisis. In global politics they have known only a post-9/11 world, the war on terror; thus, a situation of the crisis has been their norm. On a micro-level approach symbolic violence, as bullying has gone online via 
social media. Hence, on a macro level or at a micro level the threat of personal harm is constant, as a defining characteristic for this generation. In an effort to deal with these difficulties rising from a continuous liquid micro and macro framework in crisis, Generation Z's members are highly informed and want to take charge of their lives and their futures (Mack \& Palley, 2012; Merrinam, 2015), as the liquidizing powers have moved from 'system' to 'society', from 'politics' to 'life-policies' - or have descended from the 'macro' to the 'micro' level of social cohabitation (Bauman, 2000, p.7).

\section{Methodological approach and Research design}

A questionnaire exploring the experiences of students as they encountered university elearning provision was developed by the research team.

The survey instrument was built with reference to the prior surveys conducted within a similar framework by Adamopoulou et al from 2006 to 2018.

Data collection of the survey begun on March 31, 2020 with a questionnaire posted on google forms, on a convenient sampling basis. The questionnaire was sent from the platform of asynchronous learning (eclass) to the students' emails in Departments at the University of Patras covering four subjects of study (see below 5.1), and via Facebook. The survey was conducted from March 31 to April 17, 2020, with a sample of 331 students. The data concern students from the Departments of the University of Patras: (i) Education and Social Work, (ii) Educational Sciences and Early Childhood Education, (iii) Electrical and Computer Engineering, (iv) Business Administration, (v) Management Science and Technology, and (vi) the Speech and Language Therapy.

The instrument collected data about students' use of technology for both their social life and education purposes and consisted of three sections:

a) demographic characteristics of students,

b) access to technology and use of technology in education (university study),

c) Access to social media (for social life and everyday life habits and behaviors).

The study-specific technology usage section mainly focused on exploring the frequency of use in the context of the courses, the characteristics of various types of online communication between the students, students/teaching staff and students and their institution and finally, student approaches to using ICT on the courses under study.

Convenience sampling, as a non-probability sampling technique, was selected since it permits researchers to select subjects based on their convenient accessibility.

Finally, the fact that the participants were volunteers and the online version of the questionnaire places further constraints on the researcher's ability to generalize the study's results. 


\section{Presentation of findings}

\subsection{Sample description}

Out of the 331 participants, $23 \%$ (76) were boys and $75.8 \%$ (251) were girls, while 4 did not report gender.

Regarding the subject of studies, according to initial categories in the ISCED classification, 45.3\% (150) belonged to the category "Education", 23.3\% (77) to the category "Engineering, Construction", 15.4\% (51) in the category "Health Sciences \& Social Welfare", 13.3\% (44) in the category "Business" and 5 participants in other categories, while 4 participants did not respond.

As for the year of study, 27\% were in their 1 st year of study, $18.1 \%$ in the 2 nd year, $19.7 \%$ in their 3 rd year, $20 \%$ (88) in their 4 th year, $4.5 \%$ in their 5 th year and $9.8 \%$ were in their 6th year of study or more.

Also, out of the 331 participants, $53.2 \%$ of the students have a sibling, $25.1 \%$ have two siblings, $8.5 \%$ have no siblings and $7.3 \%$ have 3 siblings.

As for the education of their parents, $15.4 \%$ of the students' parents have both finished elementary school, $12.1 \%$ have finished junior high school, $21.5 \%$ have finished high school, $6.9 \%$ have finished technical school, $21.8 \%$ have graduated from university and 3\% of students' parents both have done postgraduate studies. Nine students have a father with a Ph.D. and two have a mother with a Ph.D.

In terms of family income, $3.3 \%$ of students characterize their family income as very low, $20.2 \%$ as low, $61.6 \%$ as medium, and $11.8 \%$ as high.

A large number of participants $(44.1 \%)$ responded positively on volunteering; being either for refugee solidarity groups $(1.8 \%)$ or environmental organizations $(4.8 \%)$ or something else (37.5\%).

One in four $(25.0 \%)$ respondents participates in an amateur group, i.e. music $(7.9 \%)$ or dance $(11.8 \%)$ or theater group $(5.4 \%)$, while $12 \%$ of the participants have their own blog or YouTube channel.

Almost all participants (92.7\%) exercise either in a structured setting, e.g. gym, football, dance $(54.7 \%)$, or with friends, e.g. football, basketball, etc. $(8.1 \%)$.

$19.6 \%$ of the participants smoke.

More than three out of four $(77.0 \%)$ have a certificate of high knowledge of English language; B2 level (29.4\%) and C level (47.4\%). One in five (20.2\%) possesses a computer skills certification (ECDL).

\subsection{Access to technology and the use of technology in education (university study) a. Familiar with technology since childhood}

Almost 4 out of $10(38.7 \%)$ participating in the sample stated that they have a computer since elementary school and about 2 out of 10 (16.9\%) since junior high school. $58 \%$ of the sample state that they have smartphones since junior high school and $20.8 \%$ since high school, whereas only 3 students said they do not have a smartphone. In terms of internet connection, nearly half of the sample (45.9\%) state that they have access to the internet 
since elementary school and $35.8 \%$ since junior high school while only $8 \%$ at high school and $4.6 \%$ at university. 4 students state that they do not have internet access and 9 students got Internet access within the last month. Out of the 164 people who said they were connected to VDSL, $18.4 \%$ have it since elementary school, $8.5 \%$ since high school, and $10.0 \%$ since university.

\section{b. Smartphone and computer}

In order to investigate the use and duration of using smartphones and computers, students were asked to state on a five-point scale (i.e. not at all, 1-2 hours, 3-5 hours, 6-8 hours, constantly), how much do they use the smartphone daily and how much the computer for accessing: social media, Internet, TV, YouTube, the platform for asynchronous learning (e-class) and online learning, either now (in quarantine) or before. Data concerning the Median and Mode of daily use, by reason of use, cell phone and computer before and during quarantine, are presented in Table 2.

Table 2: Reasons for use and duration of use

(hours per day) of the smart phone and computer - median, mode

\begin{tabular}{|c|c|c|c|c|c|c|c|c|c|c|c|c|c|}
\hline & & \multicolumn{2}{|c|}{$\begin{array}{l}\text { Social } \\
\text { media }\end{array}$} & \multicolumn{2}{|c|}{ Internet } & \multicolumn{2}{|c|}{ tv } & \multicolumn{2}{|c|}{ YouTube } & \multicolumn{2}{|c|}{ eclass } & \multicolumn{2}{|c|}{$\begin{array}{c}\text { Online } \\
\text { learning }\end{array}$} \\
\hline & & 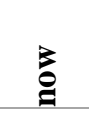 & 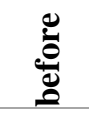 & 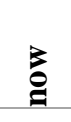 & $\frac{\grave{d}}{\stackrel{0}{J}}$ & 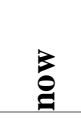 & 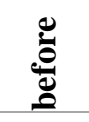 & 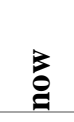 & 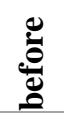 & $\stackrel{z}{g}$ & 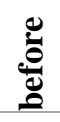 & $\stackrel{8}{g}$ & 这 \\
\hline \multirow{2}{*}{ 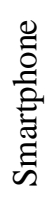 } & Median & $3-5$ & $3-5$ & $3-5$ & $1-2$ & $1-2$ & $\begin{array}{l}\text { not } \\
\text { at all }\end{array}$ & $1-2$ & $1-2$ & $1-2$ & $1-2$ & $1-2$ & $\begin{array}{l}\text { not } \\
\text { at all }\end{array}$ \\
\hline & Mode & $1-2$ & $1-2$ & $1-2$ & $1-2$ & $\begin{array}{l}\text { not } \\
\text { at all }\end{array}$ & $\begin{array}{l}\text { not } \\
\text { at all }\end{array}$ & $1-2$ & $1-2$ & $1-2$ & $1-2$ & $\begin{array}{l}\text { not } \\
\text { at all }\end{array}$ & $\begin{array}{l}\text { not } \\
\text { at all }\end{array}$ \\
\hline \multirow{2}{*}{ 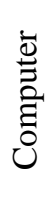 } & Median & $1-2$ & $\begin{array}{l}\text { not } \\
\text { at all }\end{array}$ & $3-5$ & $1-2$ & $\begin{array}{l}\text { not } \\
\text { at all }\end{array}$ & $\begin{array}{l}\text { not } \\
\text { at all }\end{array}$ & $1-2$ & $1-2$ & $1-2$ & $1-2$ & $3-5$ & $\begin{array}{l}\text { not } \\
\text { at all }\end{array}$ \\
\hline & Mode & $\begin{array}{l}\text { not } \\
\text { at all }\end{array}$ & $\begin{array}{l}\text { not } \\
\text { at all }\end{array}$ & $1-2$ & $1-2$ & $\begin{array}{l}\text { not } \\
\text { at all }\end{array}$ & $\begin{array}{l}\text { not } \\
\text { at all }\end{array}$ & $1-2$ & $1-2$ & $1-2$ & $1-2$ & $3-5$ & $\begin{array}{l}\text { not } \\
\text { at all }\end{array}$ \\
\hline
\end{tabular}

Table 3: Reasons for use and duration of use of the smart phone and computer - comparison means $(1=$ not at all, ... 5=always $)$

\begin{tabular}{|c|c|c|c|c|c|c|c|c|c|c|c|c|}
\hline $\begin{array}{l}\text { Mean. } \\
\text { (St. D.) }\end{array}$ & & & Int & rnet & & & You & Tube & & & & \\
\hline & 言 & 苛 & 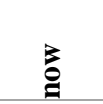 & 䒕 & 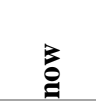 & 䒕 & 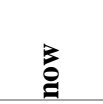 & 苋 & 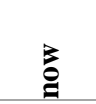 & 苛 & 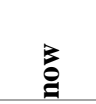 & 苛 \\
\hline 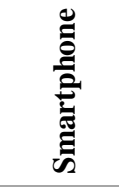 & $\begin{array}{c}2.95 \\
(1.16)\end{array}$ & $\begin{array}{c}2.65 \\
(0.91)\end{array}$ & $\begin{array}{c}2.99 \\
(1.31)\end{array}$ & $\begin{array}{l}2.66 \\
(1.08)\end{array}$ & $\begin{array}{c}1.73 \\
(0.86)\end{array}$ & $\begin{array}{c}1.52 \\
(0.76)\end{array}$ & $\begin{array}{c}2.28 \\
(0.98)\end{array}$ & $\begin{array}{c}2.25 \\
(0.84)\end{array}$ & $\begin{array}{l}2.16 \\
(0.95)\end{array}$ & $\begin{array}{c}1.86 \\
(0.68)\end{array}$ & $\begin{array}{c}2.13 \\
(1.06)\end{array}$ & $\begin{array}{c}1.12 \\
(0.47)\end{array}$ \\
\hline $\begin{array}{l}\bar{\Xi} \\
\bar{\Xi} \\
\bar{\Xi}\end{array}$ & $\begin{array}{c}1.90 \\
(1.15)\end{array}$ & $\begin{array}{c}1.61 \\
(0.89)\end{array}$ & $\begin{array}{c}3.02 \\
(1.33)\end{array}$ & $\begin{array}{c}2.4 \\
(1.07)\end{array}$ & $\begin{array}{c}1.43 \\
(0.72)\end{array}$ & $\begin{array}{c}1.20 \\
(0.60)\end{array}$ & $\begin{array}{c}2.12 \\
(1.05)\end{array}$ & $\begin{array}{c}1.98 \\
(0.96)\end{array}$ & $\begin{array}{c}2.52 \\
(0.97)\end{array}$ & $\begin{array}{c}1.99 \\
(0.69)\end{array}$ & $\begin{array}{c}2.67 \\
(0.95)\end{array}$ & $\begin{array}{c}1.18 \\
(0.53)\end{array}$ \\
\hline
\end{tabular}




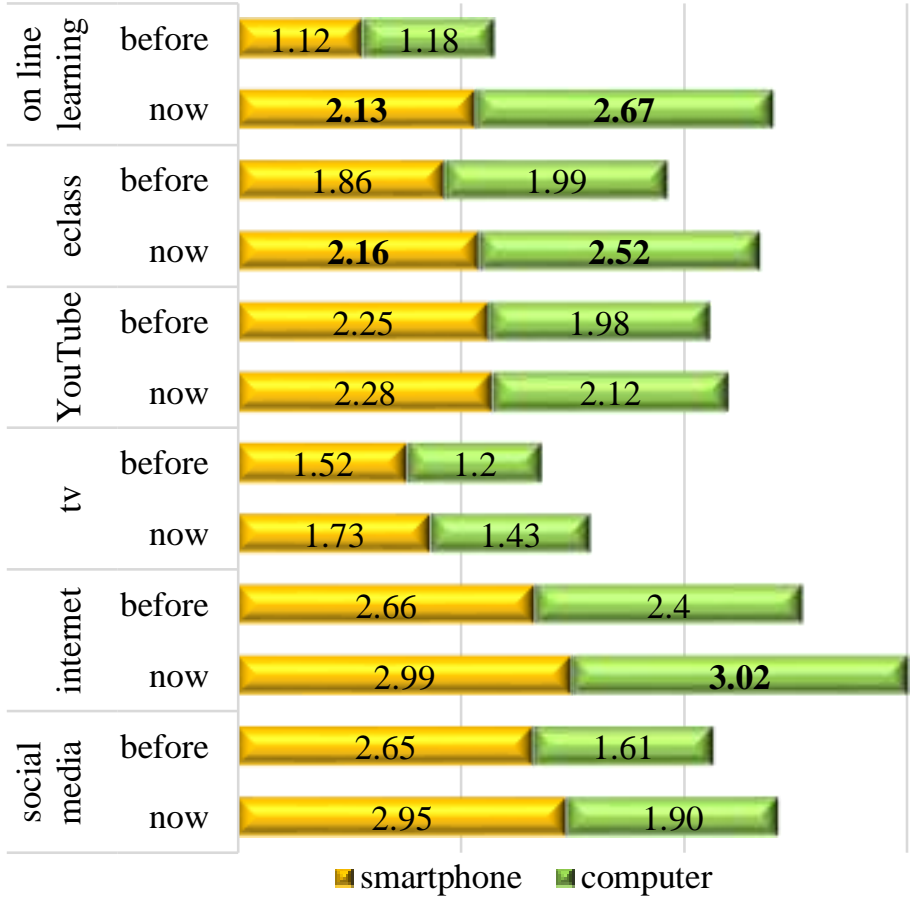

Figure 1: Reasons for the use and duration of use of the smartphone and computer - Means. (1= not at all, ... 5=always)

As we observe in Figure 1 all average rates of student attendance via smartphone and computer daily have increased very little now (in quarantine) compared to the previous situation. The only notable increases in averages are: access via smartphone and computer, eclass and e-learning, as well as access to the internet via computer.

Attending e-learning showed the largest paired differences, statistically significant differences, both via smartphone (1.019) and computer (1.486) (paired-samples t-test, $\mathrm{p}=0.00)$. In addition, statistically significant differences were observed in the access to eclass both via cell phone (0.2928) and via computer $(0.528)$, as well as the use of the internet via computer $(0.618)$ (paired-samples $\mathrm{t}$ - test, $\mathrm{p}<0.05)$.

\section{c. What they use during their studies}

Table 4: What software solutions or applications they use

\begin{tabular}{|l|c|c|c|}
\hline & Never & Sometimes & Many times \\
\hline Automatic spelling checker & 28.7 & 37.8 & 32.9 \\
\hline Automatic table of contents in an assignment & 63.7 & 26.0 & 7.9 \\
\hline Backup of my assignments & 23.3 & 30.2 & 45.9 \\
\hline Presentation of an assignment with a computer program & 12.1 & 45.9 & 41.1 \\
\hline Create diagrams in an assignment & 32.3 & 53.2 & 13.3 \\
\hline Website creation & 84.3 & 12.4 & 2.4 \\
\hline Antivirus program on the computer & 26.0 & 38.4 & 34.1 \\
\hline Creating a simple database and adding data & 58.3 & 33.2 & 6.0 \\
\hline Automatic google translator & 37.2 & 43.8 & 17.5 \\
\hline Electronic dictionaries & 27.8 & 50.8 & 19.3 \\
\hline
\end{tabular}




\begin{tabular}{|l|c|c|c|}
\hline $\begin{array}{l}\text { I have "dismantled" and "assembled" } \\
\text { the computer to upgrade to hardware }\end{array}$ & 77.0 & 14.8 & 6.6 \\
\hline \begin{tabular}{l} 
I have upgraded the computer software \\
\hline $\begin{array}{l}\text { I have installed new programs on the } \\
\text { computer on my own }\end{array}$
\end{tabular} & 51.4 & 31.1 & 15.7 \\
\hline
\end{tabular}

As we see in Table 4, large percentages of students have never created a website (84.3\%), have never dismantled-assembled their computer (77.0\%), have never used an automatic table of contents $(63.7 \%)$, have not created a database $(58.3 \%)$ and have never done software upgrade $(51.4 \%)$. On the contrary, large percentages of students use - sometimes or often - an automatic spelling checker, backup their assignments, do assignment presentations on the computer and draw diagrams. Moreover, almost one in two students sometimes use automatic google translator and electronic dictionaries. Finally, more than one in three has installed new programs on the computer sometimes and more than one in three has done it for many times.

\section{d. Where they get information on their studies}

Table 5 presents the percentages of ways students are informed about their studies at the moment, in quarantine, compared to the previous (normal) situation.

Table 5: Ways that are informed about their studies, now (in quarantine) in relation to the previous situation

\begin{tabular}{|l|c|c|c|c|c|c|}
\hline & Never & $\begin{array}{c}\text { Less } \\
\text { Now }\end{array}$ & $\begin{array}{c}\text { As } \\
\text { Previously }\end{array}$ & $\begin{array}{c}\text { More } \\
\text { Now }\end{array}$ & $\begin{array}{c}\text { I didn't, but } \\
\text { I'm doing it now }\end{array}$ & $\begin{array}{c}\text { Not } \\
\text { answer }\end{array}$ \\
\hline Social media & 17.2 & 3.9 & 47.1 & 25.7 & 3.3 & 2.7 \\
\hline Gmail & 38.4 & 1.2 & 29.6 & 26.0 & 1.8 & 3.0 \\
\hline Official mail & 13.3 & 1.8 & 33.2 & 46.5 & 2.1 & 3.0 \\
\hline Eclass & 0.9 & 0.9 & 34.1 & 61.6 & 0.9 & 1.5 \\
\hline Site of department & 10.6 & 5.4 & 49.2 & 31.7 & 0.9 & 2.1 \\
\hline Site of university & 21.5 & 5.4 & 40.5 & 26.9 & 1.8 & 3.9 \\
\hline $\begin{array}{l}\text { From the announcements } \\
\text { to the secretariat }\end{array}$ & 30.5 & 8.8 & 42.6 & 14.5 & 0.6 & 3.0 \\
\hline By fellow students & 4.5 & 7.3 & 52.9 & 32.3 & 0.9 & 2.1 \\
\hline Online learning & 6.0 & 0.9 & 9.1 & 54.1 & 28.7 & 1.2 \\
\hline
\end{tabular}

According to Figure 2 below, it is clear that there exist three sites of information for the students about their studies which have now show increase as compared to the previous (normal) situation. More students now than before, 61.6\% use "eclass" for information, $54.1 \%$ "online learning lessons" and $46.5 \%$ "official mail". 


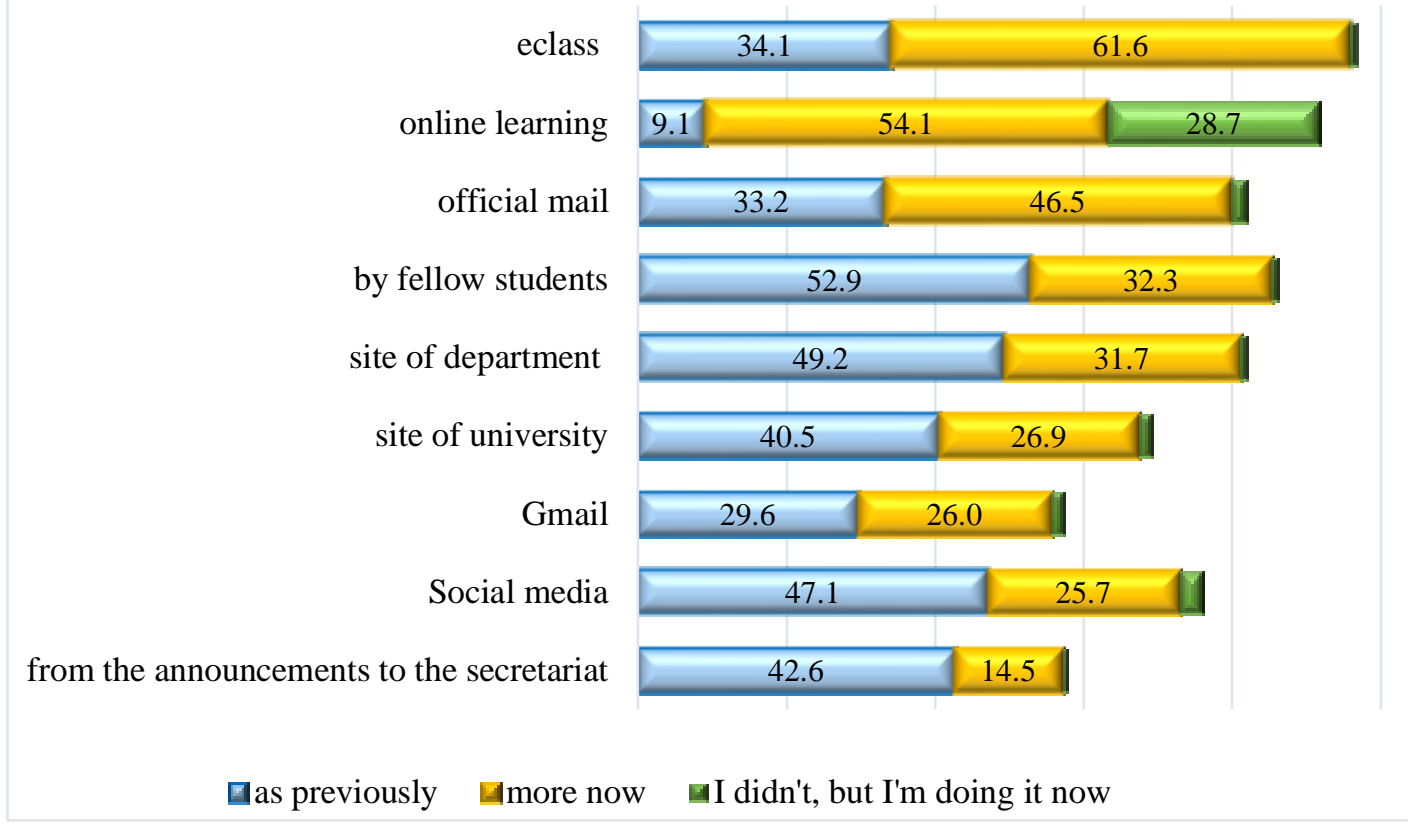

Figure 2: Ways that students are informed about their studies, now (in quarantine) in relation to the previous situation

\section{e. What they do concerning their studies}

In order to investigate the workload (that is, what students do during the semester about courses, apart from attending) before and now, there was a list with the possibility of multiple choices in the questionnaire. As we observe in Table 6, the highest percentages in the previous (normal) situation concerns assignments (54.7\%), additional assignments $(62.2 \%)$, and studying at home after the lecture (48.9\%). Furthermore, $29.0 \%$ stated that they study after the lecture using the textbook and/or electronic sources. It is also worth noting that the lowest percentage in the previous (normal) situation, i.e. 23.9\%, recorded the option to study before attending an eclass. However, as compared to the current situation (quarantine), despite the fact that this option demonstrates a slightly higher percentage (i.e. $30.8 \%$ ) it ranks as the highest selection of what students are doing now. Nowadays, $22.1 \%$ of the students' study using their notes after the lecture (online learning), $40 \%$ are doing final assignments or additional assignments and $13.3 \%$ are searching at online resources related to the subject of the lecture.

Table 6: What they do during the semester (multiple options)

\begin{tabular}{|c|c|c|c|c|}
\hline & \multicolumn{2}{|c|}{ Now } & \multicolumn{2}{|c|}{ Before } \\
\hline & $\mathrm{N}$ & $\%$ & $\mathrm{~N}$ & $\%$ \\
\hline I take on final assignments for the course when possible & 67 & 20.2 & 181 & 54.7 \\
\hline I take on additional assignments for the course when possible & 65 & 19.6 & 206 & 62.2 \\
\hline Before the lecture, I study at home the corresponding slides on eclass & 102 & 30.8 & 79 & 23.9 \\
\hline After the lecture, I study my notes at home & 73 & 22.1 & 162 & 48.9 \\
\hline $\begin{array}{l}\text { After attending the class, I study at home the corresponding } \\
\text { subject in the book }\end{array}$ & 29 & 8.8 & 96 & 29.0 \\
\hline After the lecture, I search online sources for the corresponding topic & 44 & 13.3 & 96 & 29.0 \\
\hline Total answers & 380 & & 820 & \\
\hline
\end{tabular}




\section{f. Where they study from}

In the section looking at "which sources" students studied from in the previous (normal) situation, during the semester and the exams periods, the answers were on a four-point scale (never, rarely, often, almost every day). Conversely, as to which sources students' study from now (in quarantine), there were two open questions, where they study from during the semester and where they are thinking of studying from for the exams.

Table 7 presents the percentages often/almost every day for the previous (normal) situation, while Tables 8 and 9 portray the first five categorized answers.

As we can see in tables 7, 8 and 9, the highest percentages concern "slides of the professor (lecturer) on eclass" both during the semester and during the exams in both the previous and the current situation. The option "my (own) notes" follows, while more than one in three said that in the previous situation during the semester, they searched for online sources on their own or those suggested by the professor (lecturer). It is worth noting that in the open question where you study from now (i.e. during the quarantine), apart from the other answers, $15.5 \%$ stated that they study more or every day.

Table 7: Where (which sources) the students studied from during the semester and the exams

\begin{tabular}{|l|c|c|}
\hline Often / almost every day & Semester & Exams \\
\hline Professor's slides on eclass & 85.2 & 93.4 \\
\hline My notes from attending the class & 73.7 & 90.0 \\
\hline The textbook of the lesson I had received from Eudoxus & 43.8 & 71.3 \\
\hline Online sources relevant to the course, which I search for on my own & 35.6 & 32.3 \\
\hline Online sources suggested by the professor in class & 34.7 & 31.4 \\
\hline The notes of other fellow students from attending the class & 23.9 & 46.8 \\
\hline Books in the university library proposed by the professor in class & 10.9 & 0.0 \\
\hline Other & 8.5 & 7.3 \\
\hline
\end{tabular}

${ }^{*}$ Eudoxus is the central system for circulation of textbooks which are given free of any charge to all Greek students (one textbook per course).

Table 8: Where they study from now, during the semester - categorized answers

\begin{tabular}{|l|c|c|}
\hline SEMESTER - first five options & $\mathbf{\%} \mathbf{v = 3 3 1}$ & $\mathbf{\%} \mathbf{v = 4 2 7}$ \\
\hline Professor's slides/notes on eclass & 26.9 & 34.7 \\
\hline My notes from distance learning & 23.4 & 30.2 \\
\hline I study more than before or every day & 15.5 & 19.9 \\
\hline Semester final assignments/weekly assignments & 13.3 & 17.2 \\
\hline My notes from previous course attendance & 10.8 & 13.9 \\
\hline Total answers $=427$ & & \\
\hline
\end{tabular}




\begin{tabular}{l}
\hline Table 9: Where they are thinking of studying from now for the exams - categorized answers \\
\begin{tabular}{|l|c|c|}
\hline EXAMINATIONS - first five options & $\mathbf{\%} \mathbf{v} \mathbf{3 3 1}$ & $\mathbf{\%} \mathbf{v}=\mathbf{5 4 5}$ \\
\hline slides and notes of the professor & 39.8 & 65.6 \\
\hline my notes from attending the class & 27.0 & 44.4 \\
\hline the textbook that I will receive from Eudoxus (if received) & 22.6 & 37.2 \\
\hline the notes of other fellow students from attending the class & 2.8 & 4.5 \\
\hline online sources suggested by the professor in class/online courses & 2.8 & 4.5 \\
\hline Total answers $=545$
\end{tabular} \\
\hline
\end{tabular}

\subsection{Access to social media (for social life and everyday life attitudes and behaviors)} a. Online

In accordance to Table 10, based on the responses of the participants, it is established that the internet is used to communicate with friends; that is, $45.9 \%$ now as much as during the previous situation, and $47.4 \%$ more now. A large percentage never uses the internet to find people with common interests $(66.6 \%)$, neither to find old friends $(58.6 \%)$ nor for Dating App-Flirt chat (81.9\%). A large percentage listens to music online, 56.5\% the same as before, and $33.8 \%$ more now. More than half of the respondents are now watching movies and series more $(53.2 \%)$ and read the news $(52.6 \%)$, while there is a $7.9 \%$ who do read the news now while not before.

A very high percentage is informed through the internet for the university $33.5 \%$ the same as before and $62.8 \%$ more now) and on the developments of his/her scientific field ( $52.0 \%$ the same as before and $29.3 \%$ more now).

Table 10: For which of the following reasons did you use and are now using the internet

\begin{tabular}{|l|c|c|c|c|c|}
\hline & Never & $\begin{array}{c}\text { Less } \\
\text { now }\end{array}$ & $\begin{array}{c}\text { As } \\
\text { previously }\end{array}$ & $\begin{array}{c}\text { More } \\
\text { now }\end{array}$ & $\begin{array}{c}\text { I didn't, but I'm } \\
\text { doing it now }\end{array}$ \\
\hline Communication with friends & 1.2 & 3.6 & 45.9 & 47.4 & 1.2 \\
\hline $\begin{array}{l}\text { I'm looking for people with } \\
\text { common interest with me }\end{array}$ & 66.8 & 6.6 & 23.0 & 2.1 & 0.6 \\
\hline $\begin{array}{l}\text { I'm looking for old friends } \\
\text { and acquaintances }\end{array}$ & 58.6 & 9.1 & 21.5 & 8.2 & 1.5 \\
\hline I listen to music & 1.2 & 7.6 & 56.5 & 33.8 & 0.6 \\
\hline $\begin{array}{l}\text { I read the news on the sites and } \\
\text { online newspapers }\end{array}$ & 7.6 & 3.6 & 28.1 & 52.6 & 7.9 \\
\hline $\begin{array}{l}\text { I am informed about what is } \\
\text { happening at the university }\end{array}$ & 0.6 & 0.0 & 33.5 & 62.8 & 2.4 \\
\hline For gaming & 39.6 & 10.9 & 22.1 & 19.3 & 6.9 \\
\hline I watch movies and TV series & 8.2 & 7.3 & 27.5 & 53.2 & 3.6 \\
\hline For shopping & 34.4 & 24.2 & 29.0 & 10.0 & 2.1 \\
\hline $\begin{array}{l}\text { I'm looking for information about } \\
\text { my interest and hobbies }\end{array}$ & 19.9 & 7.9 & 42.0 & 27.2 & 2.4 \\
\hline I fool around when I'm bored & 5.1 & 8.2 & 37.8 & 43.5 & 5.1 \\
\hline $\begin{array}{l}\text { I keep informed about developments } \\
\text { in my discipline }\end{array}$ & 10.3 & 5.1 & 52.0 & 29.3 & 2.4 \\
\hline Dating App-flirt chat & 81.9 & 4.8 & 8.5 & 2.7 & 0.6 \\
\hline Other & 48.0 & 2.1 & 27.2 & 5.7 & 0.6 \\
\hline
\end{tabular}


Nearly $40.0 \%$ state that they never play online games, but a $6.9 \%$ that said they did not before, they do now. Interestingly, concerning online shopping, 34.4\% state they never do it, $24.2 \%$ less now, and $29.0 \%$ the same as before. Finally, $42.0 \%$ are looking for information online about their interests and hobbies the same as before and $27.2 \%$ more now, whereas $37.8 \%$ 'fool around' when they are bored the same as before and $43.5 \%$ more now.

As we can see in the following Figure 3, the participants indicate five reasons for internet use that have increased during the quarantine situation. I use the internet more now in quarantine for "I am informed about what is happening at the university" the percentage almost doubled compared to previously. The same with "I watch movies and TV series and "I read the news on the sites and online newspapers". A slight increase in the percentage of internet use was observed for both "Communication with friends" and "I fool around when I'm bored".

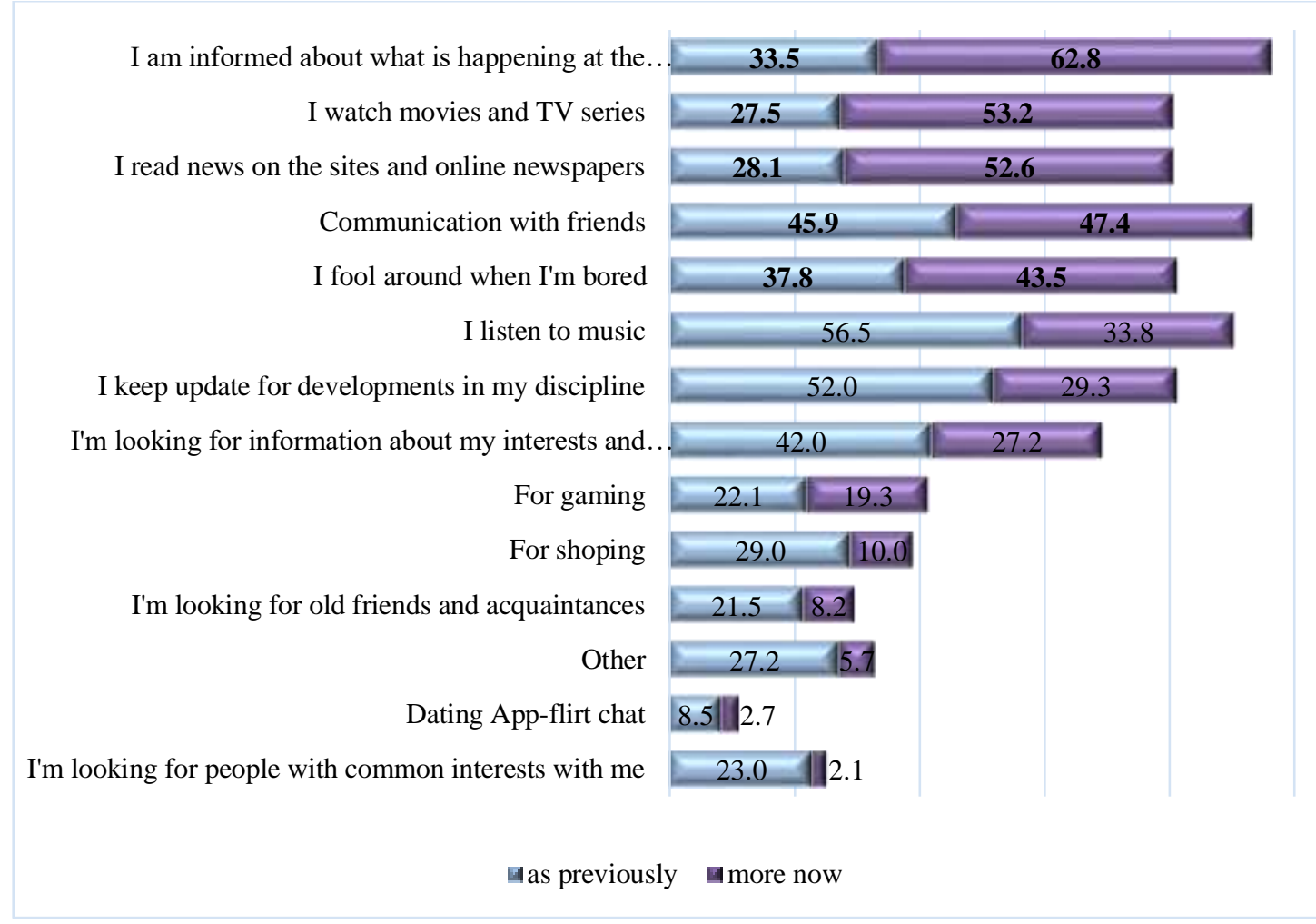

Figure 3: Reasons for using the internet - comparison

\section{b. Life}

In the previous (normal) situation (before quarantine), almost three out of four students said that 2-3 times a week (64\%) or even daily (6.6\%) went out for drinks or dinner with friends and almost one in two stayed up 2-3 times a week (35.6\%) or even daily $(6.9 \%)$ with friends at homes. 


\begin{tabular}{|l|c|c|c|c|}
\hline \multicolumn{4}{|c}{ Table 11: Social life } & 2-3 times \\
\hline How many times a week did you usually: & Never & Rarely & $\begin{array}{c}\text { Every } \\
\text { day }\end{array}$ \\
\hline Go (before lockdown) for a drink or a meal with friends & 1.2 & 27.5 & 64.0 & 6.6 \\
\hline Spend (before lockdown) the night with friends at home & 10.0 & 46.8 & 35.6 & 6.9 \\
\hline You spend the night at the computer & 17.5 & 35.6 & 28.4 & 17.5 \\
\hline
\end{tabular}

\section{Discussion}

While the University of Patra's students acknowledged that the university had to close because of the pandemic crisis, their emotional status was strongly negative (77\%, Karalis \& Raikou, 2020; p.491). Nevertheless, upon the beginning of electronic classes, the dominant emotions turned into positive ones (95\%, Karalis \& Raikou, 2020; p.491). Regarding the teaching method, electronic classes and the use of digital technologies was not a negative factor.

According to our data, the common characteristic of young Greek students attending the University of Patras is that they widely use technological media and can reach the kind of natural fluency that comes with having grown up with new digital technologies.

The students in our sample, for as long as they were in quarantine, were using their smartphone for almost three to five hours daily to access social media and the Internet. The computer was used mainly for Internet access for more than three to five hours, and equally for e-learning also on a daily basis. In other words, we could say that for a substantial six to ten hours per day more than half of the students are "connected" to some kind of digital platform. Consequently, it is important to note the increased access via smartphones and computers to e-class and e-learning, as well as the increased access to the internet via computer, compared to the previous (normal) situation. (Figure $1)$.

In the Dell Technologies survey, where 12,000 secondary and post-secondary students (Gen Z) took part and were questioned about their tech skills, the results indicate similar characteristics of confidence. According to the study, those born after the mid1990s and Generation $Z$ are tech-savvy, digital natives to the core. They bring new skills and high expectations. Gen Zs were born into technology. They have used technology as part of their formal education (98\%), say that technology literacy matters (97\%), believe that technology and automation will create a more equitable work environment $(80 \%)$, and rank their technological literacy as good or excellent (73\%) (Dimensional Research 2018) $)^{\mathrm{ii}}$.

\footnotetext{
ii Survey conducted by Dimensional Research on behalf of Dell Technologies, from August to September 2018. Dell Technologies surveyed 12,000 high school and college students, ages 16-23, Representing 17 countries around the globe: United States, Canada, Brazil, UK, Germany, France, Turkey, Australia/New Zealand, China, Japan, Indonesia, Singapore, Malaysia, Thailand, Vietnam, Philippines, 17 countries from around the globe about their views on technology and future careers.
} 
In our study, attending e-learning showed the largest paired differences, statistically significant, both via smartphone and via computer. Besides, statistically significant differences were observed in the access to eclass both via smartphone and via computer, as well as the use of the internet via computer (Table 3). On the contrary, as stated by Brown and Czerniewicz (2008) when looking at the case of almost all South African students who were exposed to ICTs, the use of these technologies was rarely frequent and despite the hype associated with Web 2.0 technologies, there was low use of those for teaching and learning.

Coming back to the case of the University of Patras, we note that the university was prepared much before the lockdown. The digital technology was there, well developed and maintained by a small team of experts and academic staff and it was like waiting such a massive event to be substantially tested and ultimately employed and utilized by all users being either academic, teaching and administrative staff or students. In effect, one could argue that it was a large scale simulation; a real life crash test for the system with a successful evolution. This successful implementation of the available technology is well documented given that: (i) all theoretical-type subjects and the theoretical part of laboratory classes and modelling were offered through distance learning at the University of Patras since Monday $26^{\text {th }}$ March, 2020 (quite soon after the lockdown); (ii) it was recorded that during the first two days of the respective week almost all (i.e. 91\%) of the classes were offered digitally attended by a large part of students; and (iii) it was made evident from the initial available data that the access of the 'asynchronous education' platform named "eclass" was doubled (please refer to the respective public announcements of the Committee for the educational function of the University in the conditions of COVID-19 epidemic circulated in tovima@upatras.gr and the website of the University http://www.upatras.gr). However, we should note here that alike the so-called 'normal circumstances, the digital transformation to remote teaching and digital classrooms bears and raises a variety of issues on quality, social interaction, data protection and further afield which need to be carefully discussed and tackled.

The use of digital and networking technologies for learning was not found to be entrenched in courses, nor were these technologies found to be ubiquitous in students' everyday lives. Use by South African students was found to be linked to a requirement to use technologies on the students' course and the use of technology tended to focus on course content. These findings of Web 2.0 technologies and course content in South Africa were, as noted by Brown and Czerniewicz (2008), similar to findings in the UK and the US (Johnes et al 2010). According to our data large percentages of students use, sometimes or more often, an automatic spelling checker, backup their assignments, do assignment presentations on the computer, and draw diagrams. Moreover, almost one in two students sometimes use automatic google translator and electronic dictionaries. Finally, more than one in three has installed new programs on the computer sometimes and more than one in three has done so for many times. Especially in times of the pandemic crisis, students use more than before, "eclass" for information (61.6\%), for "online learning lessons" (54.1\%) and "official mail" (46.5\%). 
As it has already been mentioned, most of our younger (university) students did not experience any difficulty in switching to online teaching, as participation in the class was easier, mainly through the possibilities offered by technology. As Gen Z's, they want the ability to learn new skills and have new experiences, but they especially prefer to communicate with coworkers in-person over any other method (43\%) and expect to learn on-the-job from coworkers or their teachers. Hence, apart from technical problems, the lack of communication was one of the main negative consequences of the pandemic and the following lockdown. Gen $\mathrm{Z}$ is eager for more human interaction. That is the main reason why they appreciated the help and the flexibility of their teachers (academic staff) during the pandemic crisis. Hence, being exposed to new ways of teaching excited some of the young students of the University of Patras, most probably because it was different, as compared to the usual process they were exposed before. As for the negative elements of online education, apart from the technical obstacles that have arisen, they are mainly related to the lack of communication and cooperation, as well as to the general restriction of social contact in the academic context (Karalis \& Raikou, 2020 p. 491).

At this point, we could identify the need for some further research which would have been interesting to look at. That is, to record the respective reactions of the academic, teaching and administrative staff and compare with the younger student population.

However, despite the encouraging findings of the study towards digital use and 'compliance' one could not neglect the fact that the students seem to be passive (minor) rather than energetic (major) users, in participating actively and utilizing their creativity. This could be another field that could be further researched and studied.

Moreover, assuming that the pandemic is more likely to accelerate history rather than reshape it, together with the available technology, it is plausible to argue that one could look at additional and alternative ways from the side of teaching aiming to offer more effective and efficient experiences to the younger students.

Finally, it is noteworthy to mention that as Gen Zs, the students of our study (comprising a large number of participants $44.1 \%$ ), volunteered either for refugee solidarity groups or environmental organizations or something else. This conclusion is in accordance with other studies on Gen Zs characteristics as Zs prefer to work as part of a team vs. working independently (58\%) aiming to develop a socially and environmentally responsible identity (38\%-Dimensional Research 2018).

\section{Conclusion}

The arguments made in relation to data in this article supports the proposition that according to their generational characteristics the Greek students at the University of Patras responded successfully and efficiently to the demands emerging from the limitation on social interaction because of the pandemic (lockdown and following university closure).

Young Greek university students used widely technological/digital media every day, for both personal and educational practices, under the pressure of social limits due 
to social distancing for Coronavirus (COVID-19). They also used social media for educational practices with the kind of natural fluency that comes with having grown up together with new digital technologies, since the experiences of young people involve multiple, complex and overlapping social and digital universes. The majority of students in our study for as long as they were in quarantine during the lockdown, they continued to use their smartphones significantly (i.e. three to five hours per day) being "connected" to some kind of digital platform (accessing social media and the Internet). Accordingly, it is important to note the respective observed increased access via smartphones and computers to eclass and e-learning, as well as to the internet via computer, as compared to the previous (normal) situation.

Moreover, as it has already been mentioned above, according to the findings of this study it is clear that as long as universities were closed most of the young students of our study did not have any difficulty in switching to online teaching, given that participation in the class was easier through the possibilities offered by technology. Also, the participants' responses show that as Gen Z's, they want to have the ability to learn new skills and make new experiences, but they do especially prefer to communicate with fellow students in-person over any other method and expect to learn from their fellow students or teachers.

This is the main reason why they appreciated the help and the flexibility of their teachers (academic staff) during the pandemic crisis, whereas the lack of communication was one of the main negative consequences of the pandemic and the lockdown.

In conclusion, respecting the limitations of the data employed in the study, by understanding the way that Greek students at the University of Patras adapted and responded to the conditions of the unprecedented COVID-19 pandemic crisis, we can then assume that it can serve as a framework for the identification and definition of the attitudes and behaviors of the Gen Zs of the university under any other crisis. Even though, the generation currently entering university is more complex than the literature would lead an observer to expect, their ability to adapt digitally has been confirmed and given prominence by the attitudes and behaviors in the current crisis and possibly for their functioning in the new normal.

\section{About the Authors}

Ioannis Kamarianos, Associate Professor of Sociology of Education at the Department of Education and Social Work at the University of Patras (Greece). He has taught sociology and sociology of education at both the undergraduate and postgraduate levels since 1997. His research interests focus on issues that concern sociology and sociology of education, citizenship, migration, and sociology of ICTs. Anthi Adamopoulou, Laboratory Teaching Staff at the Department of Education and Social Work, University of Patras (Greece).

Haris Lambropoulos (Ph.D. econ. LSE), Assistant Professor of Economics of Education at the University of Patras (Greece). His fields of interest refer to Human 
Capital, Innovation \& Entrepreneurship and HR Development. He actively participates in a variety of activities.

Georgios Stamelos is a Professor at the University of Patras (Greece). His fields of interest are Educational Policy, Higher Educational Policy, European Educational Policy and Teacher Education. He has published up to 200 works in English, French, Greek and Spanish.

\section{References}

Associated Press-NORC Center for Public Affairs Research (2020). Worries about the Coronavirus Increase. Retrieved: http://www.apnorc.org/projects/Pages/Worriesabout-the-Coronavirus-Increase.aspx. Retrieved: 20.5.2020.

Bauman Z. (2000). Liquid Modernity. London: Polity.

Bayne, S., Ross, J. (2007). The 'digital native' and 'digital immigrant': A dangerous opposition. Society for Research into Higher Education (SRHE). http://www.malts.ed.ac.uk/staff/sian/natives final.pdf. Retrieved 18.05.2020.

Bennett, S., Maton, K., \& Kervin, L. (2008). The 'digital natives' debate: A critical review of the evidence. British Journal of Educational Technology, 39(5), 775-786.

Brown C. \& Czerniewicz L. (2008). Trends in student use of ICTs in higher education in South Africa. Proceedings of the 10th Annual conference on World Wide Web Applications, Cape Town, Cape Peninsula University of Technology, 3-5 September.

https://www.researchgate.net/publication/242177717 Trends in student use of ICTs i $\underline{n}$ higher education in South Africa. Retrieved 18.05.2020.

Dimensional Research (2018). The future has arrived, are you ready for gen $z$ ? Round Rock: Dell. $\quad$ https://www.dellemc.com/en-us/collaterals/unauth/salesdocuments/solutions/gen-z-the-future-has-arrived-executive-summary.pdf. Retrieved: 20.5.2020.

Jones Ch., Ramanau R., Cross S., Healing Gr. (2010). Net generation or Digital Natives: Is there a distinct new generation entering university? Computers $\mathcal{E}$ Education 54, pp. 722-732.

Karalis, T., \& Raikou, N. (2020). Teaching at the Times of COVID-19: Inferences and Implications for Higher Education Pedagogy. International Journal of Academic Research in Business and Social Sciences, 10(5), 479-493.

Mack \& Palley (2012) Gen Z. Digital in their DNA. N.Y. JWT.

Margaryan, A., \& Littlejohn, A. (2009). Are digital natives a myth or reality?: Students' use of technologies for learning. http://www.academy.gcal.ac.uk/anoush/documents/. Retrieved: 20.5.2020.

Merriman M., (2015). What if the next big disruptor isn't a what but a who? Gen $\mathrm{Z}$ is connected, informed, and ready for business Ernst \& Young. Retrieved; www.ey.com/Publication/vwLUAssets/EY-rise-of-gen-znew-challenge-forretailers. 20.5. 2020. 
Oblinger, D. (2003). Boomers, Gen-Xers, and Millennials: Understanding the new students. Educause Review. pp. 37-47.

Oblinger, D. (2006). Listening to what we're seeing. ALT-C 2006, Heriot-Watt University. 5-7 September 2006. http://www.alt.ac.uk/docs/diana oblinger 20060905.pdf. Retrieved 20.05.2020.

Oblinger, D. G., \& Oblinger, J. L. (2005). Educating the net generation, http://www.educause.edu/ir/library/pdf/pub7101.pdf Retrieved 05.05.2020.

Palfrey, J., \& Gasser, U. (2008). Born digital: Understanding the first generation of digital natives. New York: Basic Books.

Prensky, M. (2001a) Digital natives, digital immigrants. On the horizon. NCB University Press, Vol. 9(5).

Prensky, M. (2001b). Digital natives, digital immigrants part II: Do they really think differently? On the horizon. NCB University Press, Vol. 9(6).

Prensky, M. (2009). H. Sapiens digital: From digital immigrants and digital natives to digital wisdom. Innovate, 5 (3). http://www.innovateonline.info/index.php?view=article\&id=705. Retrieved 01.05.2020.

Seemiller C .\& Meghan Grace M. (2019). Generation Z. A Century in the Making. N.Y. : Routledge.

Tapscott, D. (1998). Growing up digital: The rise of the Net generation. New York: McGrawHill.

Tapscott, D. (2008). Grown up digital: How the Net generation is changing your world. New York: McGraw-Hill. 
Ioannis Kamarianos, Anthi Adamopoulou, Haris Lambropoulos, Georgios Stamelos TOWARDS AN UNDERSTANDING OF UNIVERSITY STUDENTS'

RESPONSE IN TIMES OF PANDEMIC CRISIS (COVID-19)

Creative Commons licensing terms

Author(s) will retain the copyright of their published articles agreeing that a Creative Commons Attribution 4.0 International License (CC BY 4.0) terms will be applied to their work. Under the terms of this license, no permission is required from the author(s) or publisher for members of the community to copy, distribute, transmit or adapt the article content, providing a proper, prominent and unambiguous attribution to the authors in a manner that makes clear that the materials are being reused under permission of a Creative Commons License. Views, opinions and conclusions expressed in this research article are views, opinions and conclusions of the author(s). Open Access Publishing Group and European Journal of Education Studies shall not be responsible or answerable for any loss, damage or liability caused in relation to/arising out of conflicts of interest, copyright violations and inappropriate or inaccurate use of any kind content related or integrated into the research work. All the published works are meeting the Open Access Publishing requirements and can be freely accessed, shared, modified, distributed and used in educational, commercial and non-commercial purposes under a Creative Commons Attribution 4.0 International License (CC BY 4.0). 